\title{
In situ stress and pore pressure in the Kumano Forearc Basin, offshore SW Honshu from downhole measurements during riser drilling
}

\section{M. Saffer}

Department of Geosciences and Center for Geofluids, Geomechanics, and Geohazards, The Pennsylvania State University, University Park, Pennsylvania, USA (demian@psu.edu)

\section{P. B. Flemings}

Jackson School of Geosciences, University of Texas, Austin, Texas, USA

D. Boutt

Department of Geosciences, University of Massachusetts, Amberst, Massachusetts, USA

\section{M.-L. Doan}

Laboratoire de Géophysique et Tectonophysique, Université Joseph Fourier, Grenoble, France

\section{T. Ito}

Institute of Fluid Science, Tohoku University, Sendai, Japan

\section{McNeill}

National Oceanography Centre Southampton, University of Southampton, Southampton, UK

\section{T. Byrne}

Center for Integrative Geosciences, University of Connecticut, Storrs, Connecticut, USA

\section{Conin}

CEREGE-College de France, Aix en Provence, France

\section{W. Lin, E. Araki, N. Eguchi, and S. Toczko}

Japan Agency for Marine-Earth Science and Technology, Kochi, Japan

\section{Y. Kano}

Disaster Prevention Research Institute, Kyoto University, Kyoto, Japan

[1] In situ stress and pore pressure are key parameters governing rock deformation, yet direct measurements of these quantities are rare. During Integrated Ocean Drilling Program (IODP) Expedition \#319, we drilled through a forearc basin at the Nankai subduction zone and into the underlying accretionary prism. We used the Modular Formation Dynamics Tester tool (MDT) for the first time in IODP to measure in situ minimum stress, pore pressure, and permeability at 11 depths between 729.9 and 1533.9 mbsf. Leak-off testing at 708.6 mbsf conducted as part of drilling operations provided a second measurement of minimum stress. The MDT campaign included nine single-probe (SP) tests to measure permeability and in situ pore pressure and two dual-packer (DP) tests to measure minimum principal stress. Permeabilities defined from the SP tests range from $6.53 \times 10^{-17}$ to $4.23 \times 10^{-14} \mathrm{~m}^{2}$. Pore fluid pressures are near hydrostatic throughout the section despite 
rapid sedimentation. This is consistent with the measured hydraulic diffusivity of the sediments and suggests that the forearc basin should not trap overpressures within the upper plate of the subduction zone. Minimum principal stresses are consistently lower than the vertical stress. We estimate the maximum horizontal stress from wellbore failures at the leak-off test and shallow MDT DP test depths. The results indicate a normal or strike-slip stress regime, consistent with the observation of abundant active normal faults in the seaward-most part of the basin, and a general decrease in fault activity in the vicinity of Site C0009.

Components: 10,203 words, 11 figures, 3 tables.

Keywords: in situ stress; pore pressure; permeability; subduction zone; forearc basin.

Index Terms: 3025 Marine seismics; 8164 Stresses: crust and lithosphere.

Received 1 November 2012; Accepted 17 December 2012; Published XX Month 2013.

Saffer, D. M., P. B. Flemings, D. Boutt, M.-L. Doan, T. Ito, L. McNeill, T. Byrne, M. Conin, W. Lin, Y. Kano, E. Araki, N. Eguchi, and S. Toczko (2013), In situ stress and pore pressure in the Kumano Forearc Basin, offshore SW Honshu from downhole measurements during riser drilling, Geochem. Geophys. Geosyst., 14, doi:10.1002/ggge.20051.

\section{Introduction}

[2] The magnitudes of in situ pore fluid pressure and stress in subduction zones are key parameters governing rock and sediment strength and fault zone processes [e.g., Davis et al., 1983; Karig, 1990; Ito \& Obara, 2006; Scholz, 1998; Byrne \& Fisher, 1990; Saffer \& Tobin, 2011], yet direct constraints on these quantities are scarce. In scientific ocean drilling boreholes in sedimentary environments, in situ pore pressure has been measured directly at shallow depths $(<\sim 600 \mathrm{mbsf})$ using tapered probes [e.g., Flemings et al., 2008] and in a limited number of cased and sealed boreholes instrumented for long-term monitoring (known as "CORKs") [e.g., Becker et al., 1997; Davis et al., 2006; Becker \& Davis, 2005]. Direct measurements of stress magnitude in scientific boreholes are similarly rare and include attempts to measure lateral stress using probes inserted into sediment ahead of the drillbit [Moran et al., 1993] and hydraulic fracturing or leak-off tests. In the latter, an interval of the hole is isolated and fluid injected until the annular pressure exceeds the least principal stress and rock tensile strength [e.g., Zoback, 2007].

[3] Similarly, sediment and fault permeability exert a fundamental control on the potential development of anomalous fluid pressures and on fluid migration rates, pathways, and associated solute and heat transport. In situ permeability measurements have been conducted in a small number of boreholes using drill stem packer systems [e.g., Screaton et al., 1995; Fisher \& Zwart, 1996; Becker \& Davis, 2005]. More commonly, in situ permeability is extrapolated from laboratory measurements on core samples [e.g., Saffer \& McKiernan, 2005; Reece et al., 2012; Boutt et al., 2012], estimated from the pore pressure response to tidal or other transient forcing measured in instrumented boreholes [e.g., Wang \& Davis, 1996] or inferred from inverse modeling [e.g., Bekins et al., 1995; Saffer \& Bekins, 1998; Spinelli et al., 2006].

[4] In the absence of direct measurements, in situ effective stresses and pore pressure have been estimated from observed compression state (porosity) and assuming constitutive relations that link stress state and compression [e.g., Long et al., 2011] or from interval $P$-wave velocity data from which porosity is inferred [e.g., Tsuji et al., 2008; Tobin \& Saffer, 2009; Calahorrano et al., 2008]. Although indirect, these approaches have provided constraints on the regional distribution of pore pressure and stress. Estimates of in situ stress magnitude can also be obtained from observed wellbore failures if the rock or sediment strength is known [e.g., Zoback, 2007; Chang et al., 2010]. In these cases, the width of borehole breakouts (a form of compressive wellbore failure) determined from borehole imaging or azimuthal resistivity logs can be used to compute far-field horizontal stress magnitudes, under the assumption that local stresses and rock strength are equal at the edge of the breakout [e.g., Chang et al., 2010]. A number of recent studies have used this approach to estimate stresses in the hanging wall of the Nankai subduction plate boundary [Chang et al., 2010; Wu et al., 2012]. These studies have constrained the overall stress regime, but uncertainties remain large, owing primarily to poor knowledge of the rock strength. An additional 
complication arises because in soft sediment, borehole breakouts may grow over time due to temporary dilatancy-induced strengthening of sediment as a result of local stress relief associated with opening of the borehole [Moore et al., 2011].

[5] Here, we report on downhole measurements of in situ pore fluid pressure, permeability, and stress magnitude conducted as part of the first riser-based drilling in Integrated Ocean Drilling Program (IODP) at Site C0009, drilled to $1600 \mathrm{~m}$ depth into the hanging wall of the subduction plate boundary offshore SW Honshu, Japan [Saffer et al., 2010] (Figure 1). We first describe results from a suite of downhole tests using the modular dynamics formation tester (MDT; all acronyms and symbols are listed in Table 1) wireline tool designed to measure in situ formation permeability, pressure, and stress. We then discuss these results in the context of (1) permeability and its scale dependence; (2) sedimentation rates, pore pressure, and drainage state of the basin; and (3) the in situ stress regime in the upper plate of the subduction zone.

\section{Geologic Setting and Background}

[6] The Nankai Trough is formed by the northwestward subduction of the $15 \mathrm{Ma}$ Philippine Sea Plate beneath the Eurasian Plate at $41-65 \mathrm{~mm} / \mathrm{yr}$ [Seno et al., 1993; Miyazaki \& Heki, 2001] (Figure 1). Offscraping of trench turbidites and a portion of the underlying hemiplegic mudstones has formed a $\sim 100 \mathrm{~km}$-wide accretionary prism [e.g., Moore et al., 1990; Taira et al., 1991] (Figure 2). The Nankai margin has a long historical record of great $(M>8.0)$ earthquakes [Ando, 1975] and is among the most extensively studied subduction zones in the world. It has been the subject of numerous geophysical and geological studies, including seismic reflection and refraction surveys [e.g., Moore et al., 1990; 2007], ocean bottom seismometer studies [e.g., Kamei et al., 2012], and several scientific ocean drilling campaigns, including the ongoing IODP Nankai Trough Seismogenic Zone Experiment (NanTroSEIZE) [e.g., Karig et al., 1975; Kagami et al., 1986; Taira et al., 1991; Moore et al., 2001; Kinoshita et al., 2009].

[7] The NanTroSEIZE project is a coordinated scientific drilling program focused on sampling and monitoring along a transect offshore the Kii Peninsula, SW Honshu [Kinoshita et al., 2009], with the goal of better understanding subduction zone earthquakes (Figure 1). Along this corridor, the accretionary prism is cut by a major out-of sequence thrust fault, termed the "megasplay", that branches from the décollement $\sim 55 \mathrm{~km}$ from the trench and separates the $\sim 40 \mathrm{~km}$-wide actively deforming younger outer wedge and an inner wedge [e.g., Moore et al., 2007, 2009]. The Kumano Basin, a large forearc basin infilled by $\sim 2-3 \mathrm{~km}$ of Pleistocene and younger mudstones and turbidites, lies above the inner wedge [e.g., Moore et al., 2009; Ashi et al., 2009; Saffer et al., 2010] (Figures 1 and 2). The basin is bounded to the southeast by the megasplay fault

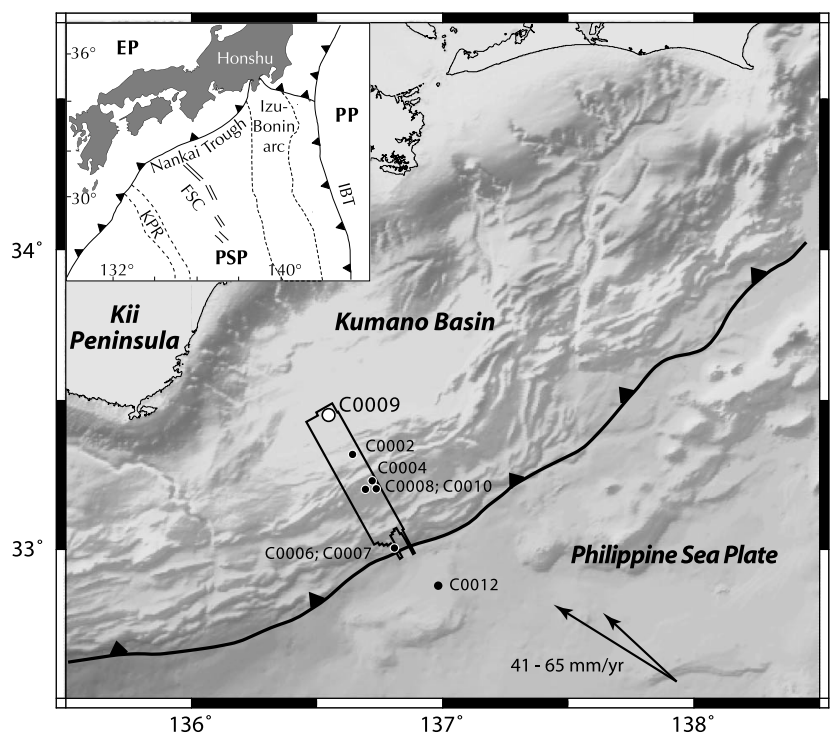

Figure 1. Map showing location of the NanTroSEIZE study area, including 3-D seismic survey (black box) and IODP drill sites. Tectonic setting shown in inset. $\mathrm{PP}=$ Pacific Plate; PSP = Philippine Sea Plate; EP=Eurasian Plate; IBT $=$ Izu-Bonin Trench; FSC $=$ Fossil Shikoku Spreading Center. 
Table 1. Acronyms and Symbols Used in Text

\begin{tabular}{|c|c|c|}
\hline Acronym & Definition & Units \\
\hline$C_{\mathrm{v}}$ & Hydraulic diffusivity & $\mathrm{L}^{2} \mathrm{~T}^{-1}$ \\
\hline DD & Dual-packer drawdown & $\mathrm{N} / \mathrm{A}$ \\
\hline DITF & Drilling-induced tensile fractures & $\mathrm{N} / \mathrm{A}$ \\
\hline DP & Dual packer & $\mathrm{N} / \mathrm{A}$ \\
\hline $\mathrm{HF}$ & Hydraulic fracturing & $\mathrm{N} / \mathrm{A}$ \\
\hline IODP & Integrated Ocean Drilling Program & $\mathrm{N} / \mathrm{A}$ \\
\hline ISIP & $\begin{array}{l}\text { Instantaneous shut-in pressure } \\
\text { (in hydraulic fracturing tests) }\end{array}$ & $\mathrm{ML}^{-1} \mathrm{~T}^{-2}$ \\
\hline$k$ & Permeability & $\mathrm{L}^{2}$ \\
\hline$K_{0}$ & Coefficient of lateral Earth pressure & Dimensionless \\
\hline LOP & Leak-off pressure (in leak-off tests) & $\mathrm{ML}^{-1} \mathrm{~T}^{-2}$ \\
\hline LOT & Leak-off test & $\mathrm{N} / \mathrm{A}$ \\
\hline $\operatorname{mbsf}$ & Meters below sea floor & $\mathrm{L}$ \\
\hline MDT & $\begin{array}{l}\text { Modular Formation Dynamics } \\
\text { Tester (Schlumberger wireline tool) }\end{array}$ & N/A \\
\hline MWD & Measurement while drilling & $\mathrm{N} / \mathrm{A}$ \\
\hline$P$ & Pressure & $\mathrm{ML}^{-1} \mathrm{~T}^{-2}$ \\
\hline$P_{\mathrm{b}}$ & Borehole pressure & $\mathrm{ML}^{-1} \mathrm{~T}^{-2}$ \\
\hline$P_{\mathrm{f}}$ & Fluid pressure & $\mathrm{ML}^{-1} \mathrm{~T}^{-2}$ \\
\hline$P_{\mathrm{h}}$ & Hydrostatic pressure & $\mathrm{ML}^{-1} \mathrm{~T}^{-2}$ \\
\hline$P_{1}$ & Lithostatic pressure & $\mathrm{ML}^{-1} \mathrm{~T}^{-2}$ \\
\hline PPG & Pounds per gallon; equivalent density & $\mathrm{N} / \mathrm{A}$ \\
\hline$S_{\text {Hmax }}$ & Maximum horizontal principal stress & $\mathrm{ML}^{-1} \mathrm{~T}^{-2}$ \\
\hline$S_{\mathrm{hmin}}$ & Minimum horizontal principal stress & $\mathrm{ML}^{-1} \mathrm{~T}^{-2}$ \\
\hline SP & Single probe & $\mathrm{N} / \mathrm{A}$ \\
\hline$S_{\mathrm{v}}$ & Vertical (overburden) stress & $\mathrm{ML}^{-1} \mathrm{~T}^{-2}$ \\
\hline $\mathrm{T}$ & Time & $\mathrm{T}$ \\
\hline $\mathrm{V}$ & Volume & $\mathrm{L}^{3}$ \\
\hline$\lambda^{*}$ & Pore pressure ratio & Dimensionless \\
\hline$\mu$ & Friction coefficient & Dimensionless \\
\hline$v$ & Dynamic viscosity & $\mathrm{ML}^{-1} \mathrm{~T}^{-1}$ \\
\hline
\end{tabular}

and likely formed in response to uplift and tilting related to fault movement [e.g., Gulick et al., 2010; Strasser et al., 2009]. Sediment accumulation rates vary spatially in the basin. Age-depth relationships defined by magneto- and biostratigraphy at IODP Site $\mathrm{C} 0002$ near the seaward edge of the basin document sedimentation rates of $\sim 560-1690 \mathrm{~m} / \mathrm{Myr}$ from $\sim 1.6$ to $0.9 \mathrm{Ma}$, decreasing to $\sim 110-350 \mathrm{~m} /$ Myr in the last $0.9 \mathrm{Myr}$ [Ashi et al., 2009]. At Site $\mathrm{C} 0009$, located $20 \mathrm{~km}$ landward of Site C0002, sedimentation rates were $\sim 180 \mathrm{~m} / \mathrm{Myr}$ from 3.8 to $\sim 1 \mathrm{Ma}$ and increased to $\sim 780 \mathrm{~m} / \mathrm{Myr}$ in the last $\sim 1 \mathrm{Myr}$, reflecting a landward shift of the depocenter [Gulick et al., 2010; Saffer et al., 2010].

[8] During Stage 1 of the NanTroSEIZE project (IODP Expeditions \#314, 315, and 316; in 20072008), seven sites were drilled into the outer accretionary prism at the frontal thrust and across the shallow megasplay fault, and one site drilled in the seaward portion of the Kumano Basin [Kinoshita et al., 2009] (Figures 1 and 2). In 2009, NanTroSEIZE Stage 2 included (1) drilling and sampling of two reference boreholes on the incoming Philippine Sea Plate to characterize the subduction "inputs" [Saito et al., 2010] and (2) drilling through the Kumano forearc basin section and into the uppermost accretionary prism or slope basin below, to a total depth of $1.6 \mathrm{~km}$ at IODP Site C0009.

[9] Drilling at Site C0009 marked the first riserbased operation in IODP history. This allowed several measurements and operations new to scientific ocean drilling, including the collection of returned drill cuttings and mud gases, the use of weighted mud, leak-off testing (LOT), and in situ downhole measurements with the Schlumberger's Modular Formation Dynamics Tester (MDT) wireline tool [Expedition 319 Scientists, 2010a, 2010b; Saffer et al., 2010; Moe et al., 2012]. One of the primary objectives of drilling at this site was to document the stress state and pore pressure below the forearc basin and above the locked and seismogenic plate boundary. Drilling at Site C0009 was also designed

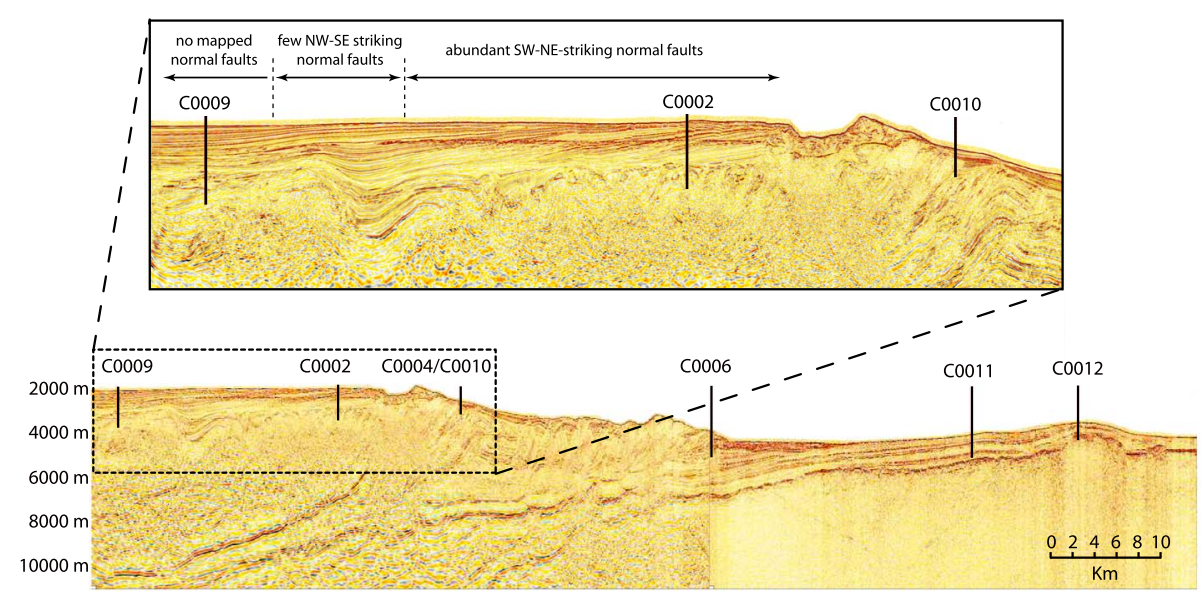

Figure 2. Regional seismic line (shown in Figure 1) showing drillsite locations (bottom) and blow-up of Kumano Basin (top). 
to serve as a trial run of the MDT tool for anticipated later riser drilling deeper into the inner accretionary prism and across major fault zones.

\section{Methods}

[10] We drilled Site C0009 from the seafloor to a depth of $712.7 \mathrm{mbsf}$ (meters below seafloor) in a riserless mode. The depth to the seafloor from the rig floor was $2082.3 \mathrm{~m}$; the ocean depth at the drillsite was $2054 \mathrm{~m}$, and the rig floor was $28.3 \mathrm{~m}$ above mean sea level [Expedition 319 Scientists, 2010b]. Downhole pressures in the LOT and MDT experiments are all referenced to the rig floor (Tables 2 and 3) because it defines the top of the mud column in the riser. After setting a wellhead and casing to $703.9 \mathrm{mbsf}$, drilling continued using the riser system. During riser operations, weighted mud was circulated while drilling, and mud gases and cuttings were collected from the returned mud at the surface [Expedition 319 Scientists, 2010a]. Drilling of the hole from 703.9 to a total depth of $1593.9 \mathrm{mbsf}$ was conducted using mud with a density of $1080-1100 \mathrm{~kg} \mathrm{~m}^{-3}$ (9.0-9.2 pounds per gallon (PPG)). Direct measurements of the static mud column pressure from the MDT tool indicate a static mud column density of $1130 \mathrm{~kg} \mathrm{~m}^{-3}$ (9.4 PPG), likely reflecting the additional weight of cuttings [Expedition 319 Scientists, 2010b].

[11] After drilling, we deployed the wireline MDT tool to measure in situ pore pressure, minimum stress magnitude, and permeability at several depth intervals from $\sim 730$ to 1540 mbsf [Expedition 319 Scientists, 2010b; Saffer et al., 2010] (Figure 3). In addition, we conducted a leak-off test at the base of casing at 703.9 mbsf as part of standard riser operations to measure the minimum principal stress. We used the MDT tool in two different modes: single probe (SP) and dual packer (DP) (Figure 4). Below, we briefly summarize the

Table 2. MDT SP Deployments and Results

\begin{tabular}{lccccccc}
\hline Test \# & $\begin{array}{c}\text { Depth } \\
(\mathrm{mbs})\end{array}$ & $\begin{array}{c}\text { Pore Pressure } \\
(\mathrm{MPa})^{\mathrm{a}}\end{array}$ & $\begin{array}{c}\text { Hydrostatic Pressure } \\
(\mathrm{MPa})\end{array}$ & $\begin{array}{c}\text { Overpressure } \\
(\mathrm{MPa})\end{array}$ & $\begin{array}{c}\text { Vertical Stress } \\
(\mathrm{MPa})\end{array}$ & $\begin{array}{c}P_{\mathrm{b}} \text {, Borehole Pressure } \\
(\mathrm{MPa})^{\mathrm{c}}\end{array}$ & $\begin{array}{c}\text { Permeability } \\
\left(\mathrm{m}^{2}\right)\end{array}$ \\
\hline $\begin{array}{l}\text { MDT- } \\
\text { 059 }\end{array}$ & 729.9 & 28.3 & 28.42 & -0.12 & 33.22 & 31.16 & $4.23 \times 10^{-14}$ \\
$\begin{array}{l}\text { MDT- } \\
\text { 080 }\end{array}$ & 874.9 & 30.8 & 29.88 & $0.92^{\mathrm{b}}$ & 36.20 & 32.81 & $1.10 \times 10^{-15}$ \\
$\begin{array}{l}\text { MDT- } \\
\text { 061 }\end{array}$ & 877.9 & 31.0 & 29.91 & $1.09^{\mathrm{b}}$ & 36.26 & 32.80 & $2.75 \times 10^{-16}$ \\
$\begin{array}{l}\text { MDT- } \\
\text { 065 }\end{array}$ & 1175.0 & 32.8 & 32.91 & -0.11 & 42.29 & 36.10 & $1.85 \times 10^{-14}$ \\
$\begin{array}{l}\text { MDT- } \\
\text { 078 }\end{array}$ & 1218.9 & 33.3 & 33.36 & -0.06 & 43.20 & 36.57 & $5.19 \times 10^{-16}$ \\
$\begin{array}{l}\text { MDT- } \\
\text { 075 }\end{array}$ & 1464.9 & 35.7 & 35.84 & $-0.14^{\mathrm{b}}$ & 48.03 & 39.30 & $6.53 \times 10^{-17}$ \\
\hline
\end{tabular}

${ }^{\mathrm{a}}$ Pressure is the total pressure taken from the rig floor, $2082.3 \mathrm{~m}$ above the seafloor.

${ }^{\mathrm{b}}$ Characterized as a low-mobility test; reported pressure should be considered a minimum value.

${ }^{\mathrm{c}}$ Borehole mud pressures shown in Figure 9 include all nine SP deployments: six listed in Table 2 and the three deployments that exhibited poor sealing in drawdown tests (not listed above): MDT-060 at $876.9 \mathrm{mbsf}, P_{\mathrm{b}}=32.77 \mathrm{MPa}$; MDT-067 at $1335.9 \mathrm{mbsf}, P_{\mathrm{b}}=37.88 \mathrm{MPa}$; MDT-074 at $1531.9 \mathrm{mbsf}, P_{\mathrm{b}}=40.04 \mathrm{MPa}$.

Table 3. MDT and LOT Stress Measurements

\begin{tabular}{lcccccc}
\hline Test & Depth $(\mathrm{mbsf})$ & $S_{\mathrm{hmin}}(\mathrm{MPa})$ & $S_{\mathrm{Hmax}}(\mathrm{MPa})$ & $S_{\mathrm{v}}(\mathrm{MPa})$ & Borehole Pressure $(\mathrm{MPa})^{\text {Pore Pressure }^{\mathrm{a}}(\mathrm{MPa})}$ \\
\hline LOT & $708.6^{\mathrm{b}}$ & $30.24^{\mathrm{c}}$ & $30.24^{\mathrm{e}}$ & 32.81 & 30.90 & 28.2 \\
MDT-080 & 876.9 & $35.0^{\mathrm{d}}$ & $39.2-39.4^{\mathrm{e}}$ & 36.25 & 32.77 & $30.8-31.0$ \\
& & $39.0-41.8^{\mathrm{f}}$ & & & \\
MDT-074 & 1533.9 & $41.6^{\mathrm{d}}$ & $55.0^{\mathrm{g}}$ & 49.42 & 40.04 & 36.5 \\
& & $41.5^{\mathrm{f}}$ & & & & \\
\hline
\end{tabular}

${ }^{a}$ Formation pore pressure is assumed to be hydrostatic except at upper MDT measurement depth (cf. Table 2)

${ }^{\mathrm{b}}$ Top of LOT interval at base of cement.

${ }^{\mathrm{c}}$ Leak-off pressure (LOP).

${ }^{\mathrm{d}}$ Instantaneous shut-in pressure (ISIP).

${ }^{\mathrm{e}}$ Computed from DITF by equation (2).

${ }^{\mathrm{f}}$ Tsuji et al. [2011].

${ }^{\mathrm{g}}$ Ito et al. [2013]. 


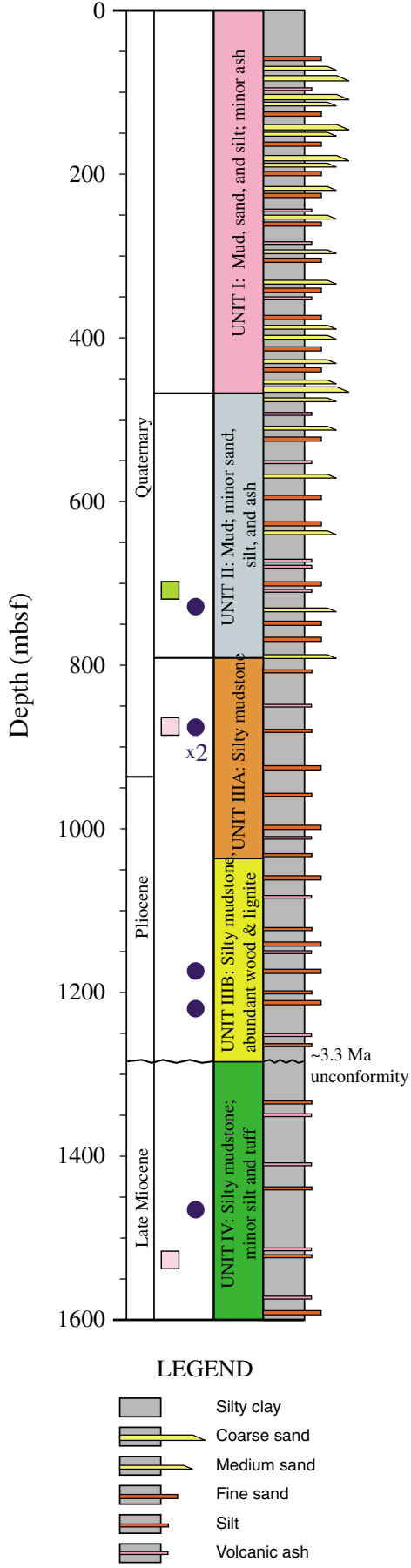

Figure 3. Summary stratigraphic column for Site C0009, showing lithologic units defined from logs and cuttings and the locations of MDT SP measurements (blue circles), dual-packer HF tests (pink squares), and the leak-off test (green square) (see also Tables 2 and 3).

method for each of these tests (for details of the operations for each test, see Moe et al. [2012], Saffer et al. [2010], and Expedition 319 Scientists [2010a]).
[12] In the SP tests, a probe was pushed against the borehole wall and isolated from the borehole by a sealing ring, and $0.5-1.0 \times 10^{-5} \mathrm{~m}^{3}$ of fluid was extracted from the formation at a rate of $3.0-8.0 \times 10^{-5} \mathrm{~m}^{3}$ $\mathrm{min}^{-1}$ to reduce the pressure. For most of our tests, the drawdown and recovery were repeated at least once (Figure 5). The fluid pressure is monitored during the test to estimate the fluid mobility (equal to permeability/viscosity) and the in situ formation pore pressure [e.g., Saffer et al., 2010; Moe et al., 2012] (Figure 5). For a vertical borehole, the semispherical flow controlling the SP test response primarily samples horizontal formation permeability [Stewart \& Wittman, 1979]. In the DP tests, an interval of the formation was isolated by two packers spaced $1 \mathrm{~m}$ apart and fluid was either (1) injected to raise the borehole pressure and generate a hydraulic fracture to measure the minimum principal stress [e.g., Zoback, 2007] (Figure 6) or (2) withdrawn to estimate formation permeability from the pressure drawdown and recovery [e.g., Boutt et al., 2012]. In total, we conducted 12 MDT measurements, including 9 SP tests and 3 DP tests (1 drawdown test and 2 hydraulic-fracture tests) (Table 2). We do not discuss the DP drawdown test here; it is described in detail elsewhere [Boutt et al., 2012]. Test intervals were selected in advance of the MDT tool deployment using Formation Micro-Imager resistivity image data, caliper, and resistivity data from previous wireline logging runs to avoid zones where the borehole wall was washed out and where the formation was obviously fractured or heterogeneous. Deployment targets were verified using gamma ray logs collected by the MDT tool and transmitted to the ship in real time. For DP tests, we chose depth intervals at least $5 \mathrm{~m}$ long where the borehole remained $<14^{3} / 4$ inches in diameter, with hole ovality (max diameter/min diameter) $<130 \%$ [Expedition 319 Scientists, 2010a].

[13] For SP tests, the permeability $\left(k\right.$, in $\left.\mathrm{m}^{2}\right)$ is defined from the pumped volume $\left(V\right.$, in $\left.\mathrm{m}^{3}\right)$, test duration ( $t$, in s), fluid dynamic viscosity ( $v$, in Pa s; the symbol " $\mu$ " is typically used to represent fluid viscosity, but we use it elsewhere in this paper for friction coefficient), and observed pressure drop $(\triangle P$, in Pa) [Stewart \& Wittman, 1979; Expedition Scientists, 2010a]:

$$
k=C V v / \Delta P t
$$

where $C$ is an empirically defined constant that depends on the probe size; for our tests, $C$ is equal to 16.5. This approach is considered reliable for permeabilities $>\sim 10^{-15} \mathrm{~m}^{2}$. Permeability has also been determined separately for the DP drawdown 


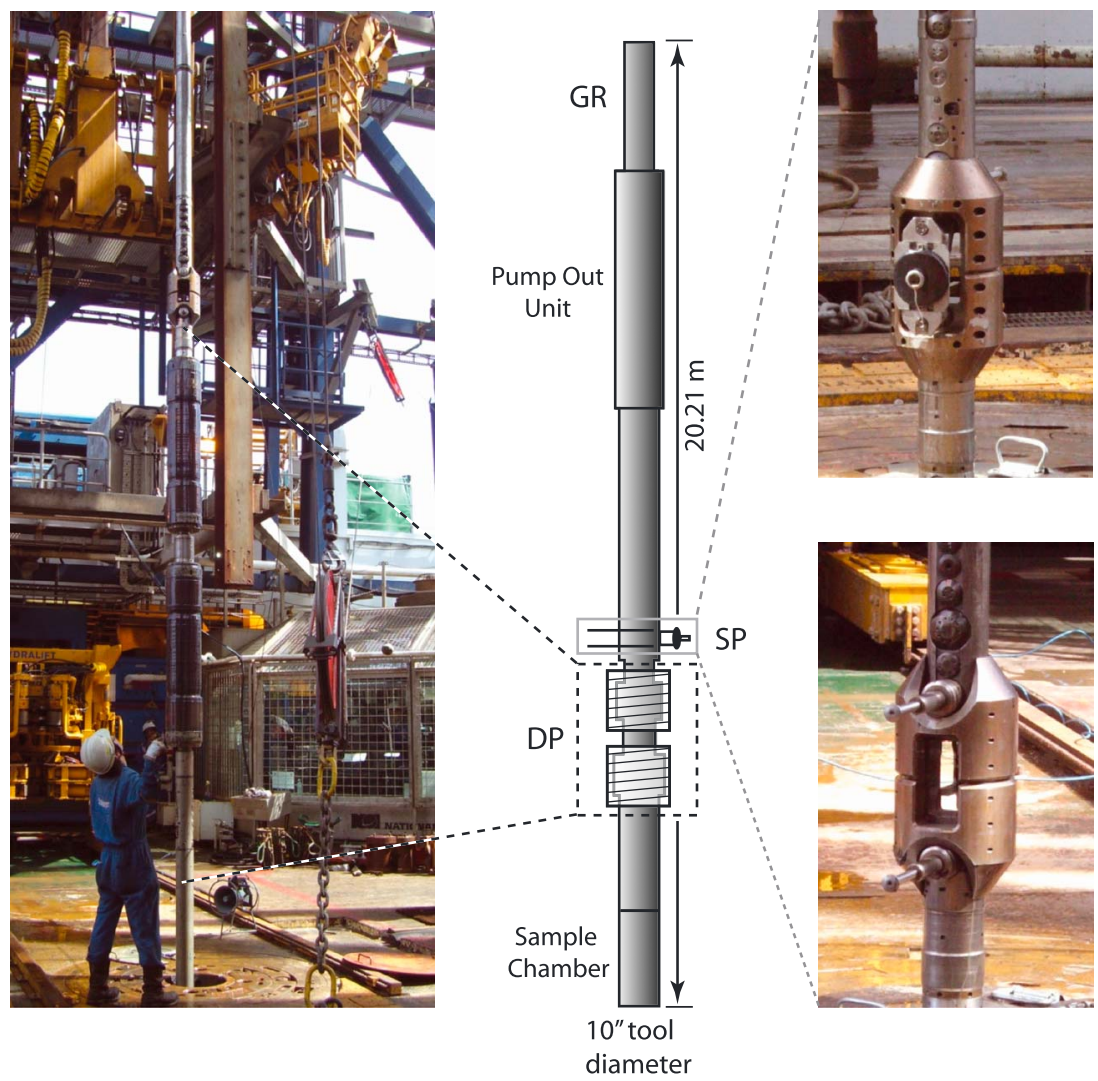

Figure 4. Schematic of MDT wireline tool (center) and photos of the dual packer (DP, left) and single probe (SP, right) elements. GR = gamma ray.
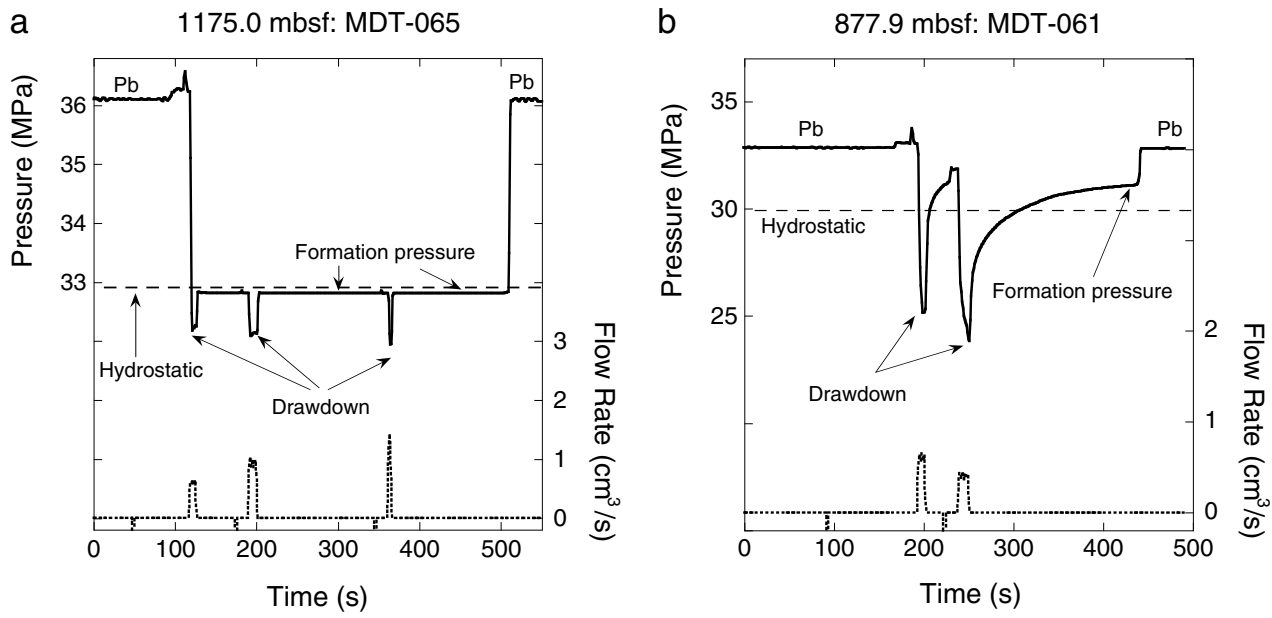

Figure 5. Example single probe deployment records, showing pressure (left axis, solid line) and pump flow rate (right axis, dotted line) (positive rate indicates fluid withdrawal) versus time. (a) "High-mobility" case characterized by rapid pressure equilibration and (b) low-mobility case characterized by slow pressure equilibration. In both cases, a good seal is indicated by the clear difference between formation pressure after drawdown and recovery and the pressure $\left(P_{\mathrm{b}}\right)$ in the open borehole measured prior to setting the tool and after retracting it. The formation pressure is taken as the final pressure during the recovery. As described in the text, the permeability of each test interval is computed from drawdown and pumping rate. Hydrostatic pressure is determined by assuming a fluid density of $1030 \mathrm{~kg} / \mathrm{m}^{3}$ extending to the sample depth. 

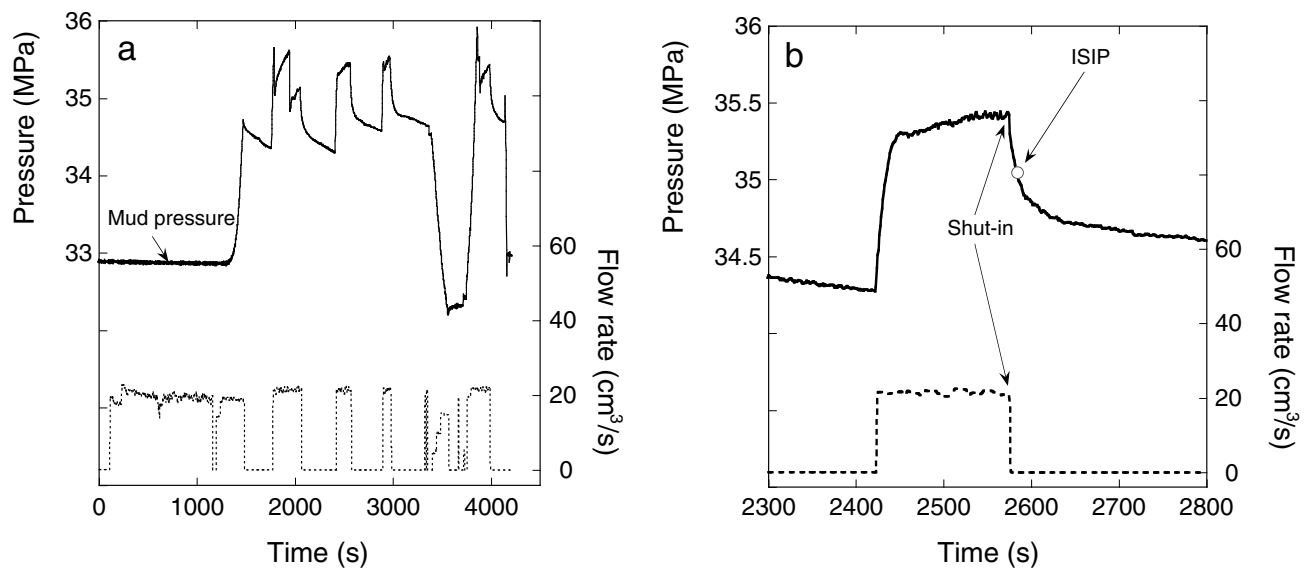

Figure 6. Hydraulic fracturing test record for the dual-packer deployment at $876.9 \mathrm{mbsf}$, showing pressure and fluid pumping rate versus time (positive flow rate indicates injection). (a) Full test record showing three repeat injection cycles. (b) Detailed view of the second injection cycle, showing the instantaneous shut-in pressure (ISIP) taken to indicate the minimum principal stress magnitude.

test and one of the DP injection tests through numerical modeling of radial flow and history matching of pumping and pore pressure records [Boutt et al., 2012]. We estimated the in situ pore fluid pressure from the final pressure during the pore pressure recovery in each test; for tests that exhibit a slow or incomplete recovery, this should be considered a minimum value (e.g., Figure $5 b$ ).

[14] In DP hydraulic-fracture tests, fluid is injected into the isolated borehole interval between the packers at a constant rate, pumping is then terminated, and the pressure is allowed to decay in order to define the minimum principal stress [e.g., Haimson \& Cornet, 2003; Zoback, 2007], with pressure in the packed interval monitored continuously (Figure 6). During the injection phase, pressure in the isolated target interval increases until a hydraulic fracture initiates. After some time following fracture initiation, pumping is stopped (i.e., the interval is "shut in"), and as a result the pressure decays. After allowing pressure to decay for some time ( 300-400 s), the pressure is released and the test repeated several times using the same flow rate to verify that the fracture has grown sufficiently away from the wellbore that the measured pressures can provide information about minimum principal stress in the formation. The instantaneous shut-in pressure (ISIP), defined by the first break in slope of the pressure decay during the shut-in phase of the test, is a measure of the minimum principal stress [e.g., Zoback, 2007].

[15] In addition to the MDT hydraulic fracturing measurements, as part of standard riser-based operations, we conducted two leak-off tests (LOTs) immediately below the base of the cement below a casing string at 703.9 mbsf [Expedition 319 Scientists, $2010 \mathrm{~b}$. The test zone for the LOT spans the interval from the bottom of the cement at $708.6 \mathrm{mbsf}$ to the bottom of the open hole below at $715.7 \mathrm{mbsf}$. In these tests, the pressure in the well is shut in at the rig floor, such that pumping additional fluid downhole increases the pressure in the open hole test interval below the casing shoe. During the LOT on Expedition \#319, fluid was pumped at a constant rate $\left(\sim 2.3 \mathrm{~m}^{3} / \mathrm{s}\right)$, and pressure at the ship's pumps was continuously monitored (Figure 7). The leak-off pressure (LOP), defined by the break in slope of the pressure-flow volume (or time) curve, represents a change in the volume of the isolated borehole interval and is generally taken to represent the initiation of a hydraulic fracture [Zoback, 2007]. The LOP is considered to closely approximate the minimum principal stress [e.g., White et al., 2002; Zoback, 2007; Expedition 319 Scientists, 2010b].

[16] In some depth intervals, drilling-induced tensile fractures (DITF) form due to stress concentration around the wellbore [e.g., Zoback, 2007]. Where DITF are observed (749-980 mbsf at Site C0009) [Lin et al., 2010], the magnitude of the far-field maximum horizontal compressive stress $\left(S_{\mathrm{Hmax}}\right)$ can be computed from the borehole pressure $\left(P_{\mathrm{b}}\right)$, measured formation pore pressure $(P)$, and the known (measured) values of minimum horizontal stress $\left(S_{\text {hmin }}\right)$ [e.g., Zoback, 2007]:

$$
S_{\mathrm{H} \max }=3 S_{\mathrm{hmin}}-P_{b}-P
$$

assuming that the sediment tensile strength is negligible. For the depth interval of the LOT, we did not obtain a measurement of formation pore fluid 

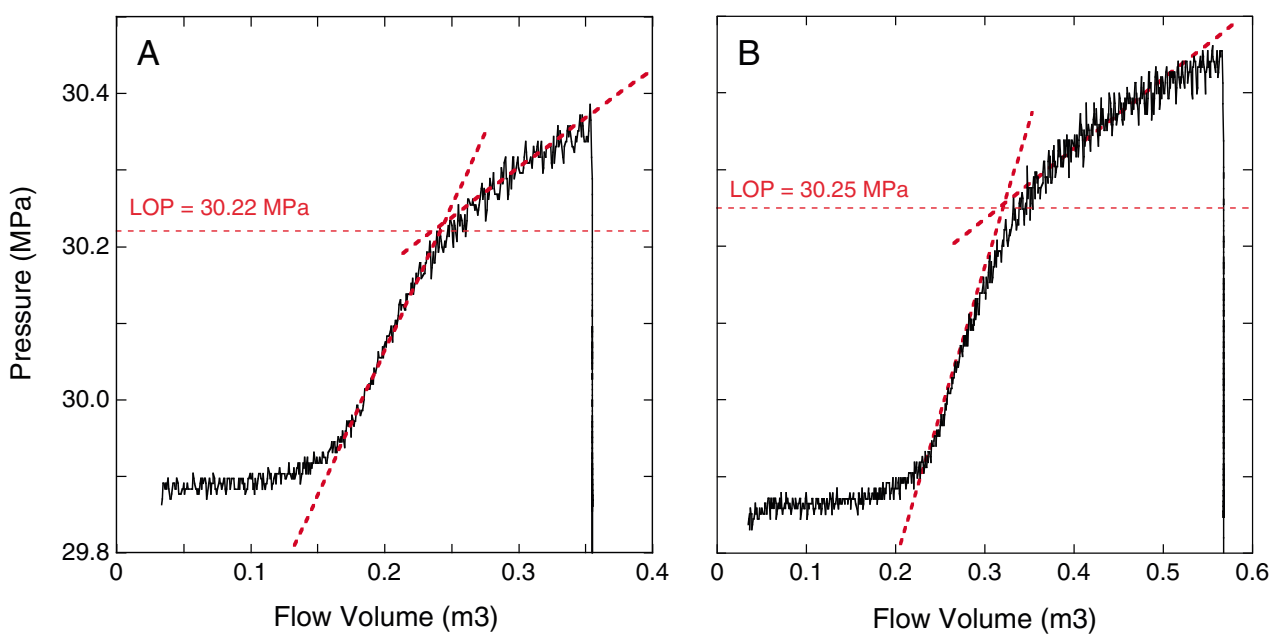

Figure 7. Leak-off test (LOT) pressure records for two repeat tests. Leak-off pressure (LOP) is given by the break in slope of the pressure-flow volume curve and is taken to represent the minimum principal stress [e.g., Zoback, 2007].

pressure, but we assume it is hydrostatic on the basis of the pore pressure profile defined by the MDT data [Saffer et al., 2010]. We determine $P_{\mathrm{b}}$ by adding (1) the static mud pressure gradient defined by measurements at the start of each MDT deployment (e.g., Figure 5), and (2) additional pressure generated by pumping and circulation during drilling. Unfortunately, $P_{\mathrm{b}}$ was not monitored during drilling of the riser hole; therefore, we estimate the circulating pressure using measuring-while-drilling (MWD) data collected during drilling the uppermost portion of the borehole prior to riser operations Expedition 319 Scientists, 2010b. The resulting values of $P_{\mathrm{b}}$ correspond to an equivalent circulating density of $\sim 1200 \mathrm{~kg} \mathrm{~m}^{-3}$ (10.1 PPG). Lower values of $P_{\mathrm{b}}$ would yield larger values of $S_{\text {Hmax }}$; therefore, we consider the values of $S_{\mathrm{Hmax}}$ we report to be minima.

\section{Results}

\subsection{Permeability and In Situ Pore Pressure}

[17] Based on shipboard assessment of the SP test data, three of the nine deployments were interpreted to exhibit poor sealing against the borehole wall Expedition 319 Scientists, 2010b. The remaining six SP deployments record good sealing: the pressure decreases rapidly as fluids are withdrawn and during shut-in, and the pore pressures then rise to a pressure distinct from the borehole pressure $\left(P_{\mathrm{b}}\right)$ (e.g., Figures $5 \mathrm{a}$ and $5 \mathrm{~b}$ ). We report only on the tests characterized by a good seal. The deployments exhibit a mix of rapid (high-mobility) type responses $(n=3)$ (Figure 5a) and low-mobility responses $(n=6)$ (Figure $5 b)$.
[18] Permeabilities computed from the MDT SP tests (by equation (1)) range from $\sim 6.5 \times 10^{-17}$ to $\sim 4 \times 10^{-14} \mathrm{~m}^{2}$ and exhibit no systematic relationship with depth or lithologic unit (Figure 8). Permeability does exhibit a weak inverse correlation with values of natural gamma ray radiation measured from wireline logs, as would be expected with increasing clay content [Saffer et al., 2010]. The estimated permeabilities vary by $\sim 1$ order of magnitude over a $3 \mathrm{~m}$ depth range from 874.9 to $877.9 \mathrm{mbsf}$ (Table 2). The SP permeabilities are systematically higher than in situ permeabilities estimated by applying laboratory-defined relationships between vertical sediment permeability and porosity for the basin fill units at Site C0002 [Guo et al., 2011] and for accretionary prism sediments from Site C0009 [Boutt et al., 2012] (Figure 8, shaded areas). The SP permeabilities are in general agreement with values computed from detailed analysis of dual-packer tests in the interval from 1533.9 to $1540.9 \mathrm{mbsf}$ (Figure 8) [Boutt et al., 2012].

[19] The SP pressure recoveries indicate that formation pore fluid pressures range from 28.3 to $35.7 \mathrm{MPa}$ (referenced to mean sea level) over the depth range from 729.9 to $1531.9 \mathrm{mbsf}$, corresponding to nearly hydrostatic pressures throughout the basin section and upper accretionary prism. In some cases, the reported pressures are very slightly $(<0.14 \mathrm{MPa})$ subhydrostatic. The apparent underpressures probably reflect incomplete recovery of pressure after drawdown in the tests; they could also result from slight overestimation of the hydrostatic pressure. Excess pore pressures are negligible at all depths, with the exception of two measurements indicating $\sim 1 \mathrm{MPa}$ of 


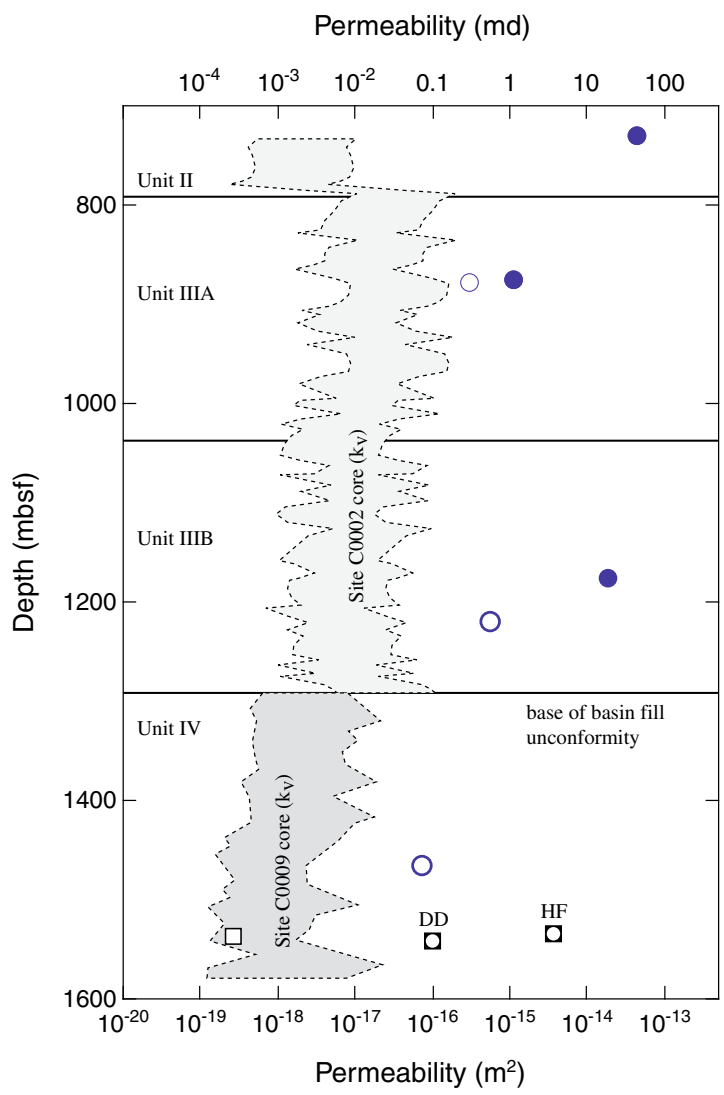

Figure 8. Permeability as a function of depth, reported in $\mathrm{m}^{2}$ (lower axis) and millidarcies (top axis). Single-probe (SP) MDT results (blue solid circles = permeability values $\geq 10^{-15} \mathrm{~m}^{2}$; open circles $=$ values $<10^{-15} \mathrm{~m}^{2}$ ) are computed from equation (1), using the appropriate viscosity for each measurement point based on the in situ temperature estimated from the thermal gradient measured at Site C0002 [Ashi et al., 2009]. As noted in text, SP permeabilities $<10^{-15} \mathrm{~m}^{2}$ may be unreliable. Permeabilities determined by Boutt et al. [2012] from modeling the pressure records for the attempted dual-packer hydraulic-fracture (HF) and dual-packer drawdown test (DD) are shown by partially filled squares. In situ permeabilities are also estimated using porosity from wireline logs at Site C0009, combined with permeability-porosity relationships defined by laboratory tests on core samples (gray-shaded regions). For Units II and III, we use data for data from Site C0002 as an analog (from Guo et al. [2011]) because no cores were collected in these units at Site C0009. For Unit IV, we use experimental data for core samples from Site C0009 ([Boutt et al., 2012] open square; Kitajima et al., unpublished data).

overpressure at 874.9 and $877.9 \mathrm{mbsf}$ (Figure 9) [Expedition 319 Scientists, 2010b]. These local overpressures may reflect in situ formation overpressures. Alternatively, "supercharging" may be present if the borehole pressure $\left(P_{\mathrm{b}}\right)$ drives fluid through the mud filtrate, leading to a measured pressure that is higher than the true formation pressure. Both overpressured measurements are characterized by low mobility (Table 2), and supercharging is most common with this type of response [Stewart \& Wittman, 1979].

\subsection{Stress Magnitudes}

[20] The two leak-off tests conducted below the casing in the interval $708.6-715.7 \mathrm{mbsf}$ yielded reproducible leak-off-pressures (LOP) of 30.22 and $30.25 \mathrm{MPa}$, as defined by the break in slope of the pressure-injection volume curve (Figure 7) [Zoback, 2007; Expedition 319 Scientists, 2010a]. We assume that the leak-off pressure approximates the least principal stress [e.g., White et al., 2002]. At this depth, the vertical stress computed from density $\operatorname{logs}$ is $\sim 32.9 \mathrm{MPa}$; therefore, the least principal stress interpreted from the leak-off stress is also $S_{\mathrm{hmin}}$ based on the assumption that the principal stresses at these depths are vertical and horizontal.

[21] During the shallow MDT DP hydraulic fracturing test at 876.9 mbsf, we conducted five injection and shut-in cycles, all using the same flow rate (Figure 6). The pressure records for each of the last four cycles are highly reproducible and yield nearly identical values of ISIP ranging from 34.82 to $35.17 \mathrm{MPa}$, which we interpret to equal the minimum principal stress Expedition 319 Scientists, 2010b. The ISIP values are lower than the vertical stress $\left(S_{\mathrm{v}}\right)$ of $\sim 36.2 \mathrm{MPa}$. The ISIP is therefore a measure of the minimum horizontal stress $S_{\mathrm{hmin}}$, again assuming that the principal stresses are vertical and horizontal.

[22] For the deeper MDT hydraulic fracturing test at 1533.9 mbsf, fluid injection during several test cycles resulted in stepwise pressure increases within the packed interval but without any change in slope as would be expected due to fracture development (i.e., "formation breakdown") [Zoback, 2007; Expedition 319 Scientists, 2010b]. After increasing the pumping rate for the last cycle, a tentative ISIP of $41.6 \mathrm{MPa}$ was obtained. However, this injection cycle was not repeated due to time constraints, and because the ISIP is not reproducible, it was deemed less reliable than the shallow measurement Expedition 319 Scientists, 2010b. Ito et al. [2013] conducted a detailed analysis of the pressure records from this test to estimate the minimum principal stress and obtained a value of $41.5 \mathrm{MPa}$. The ISIP (41.6 MPa) and minimum principal stress estimate $(41.5 \mathrm{MPa})$ are both less than 

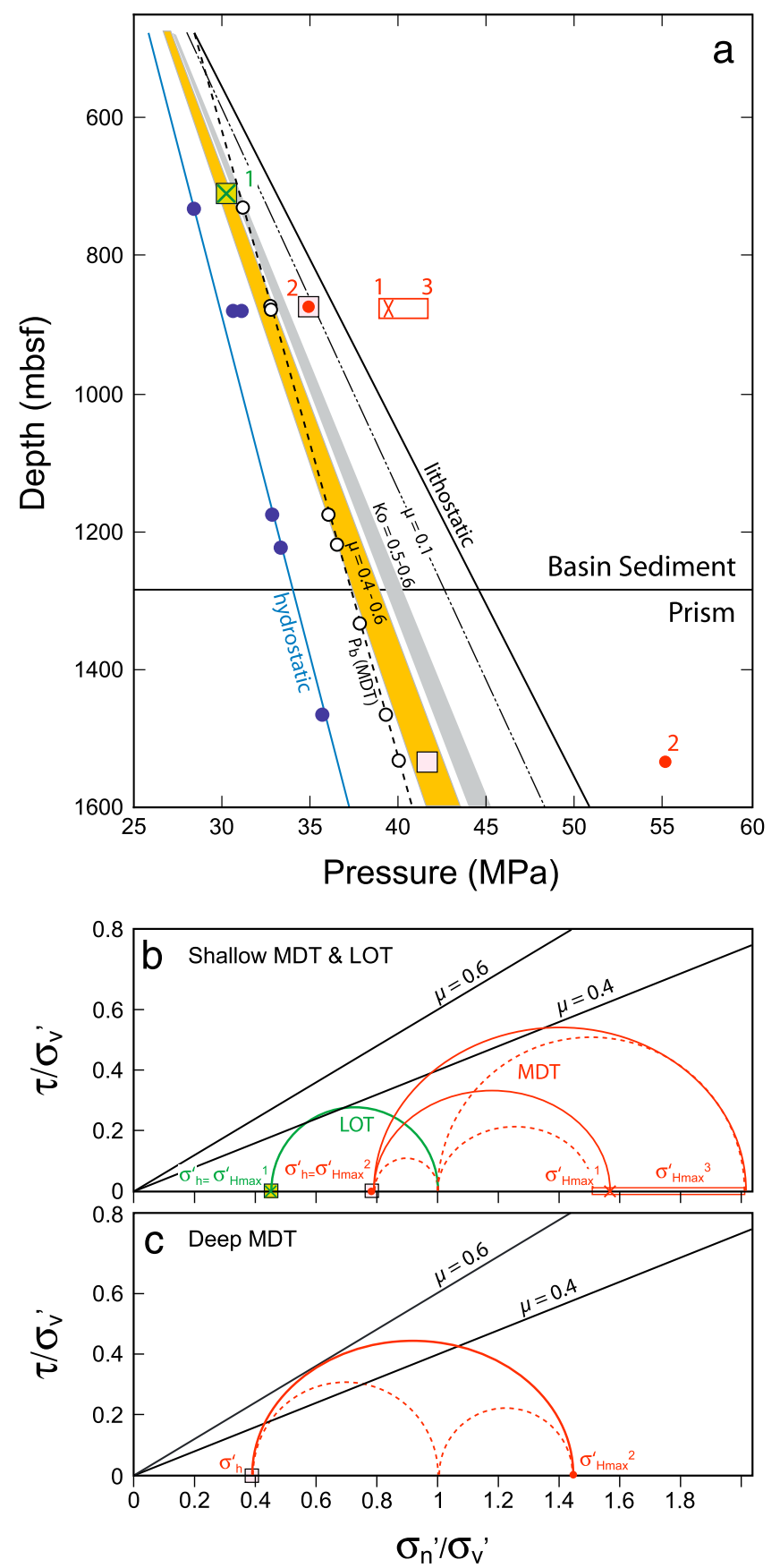

Figure 9. (a) Profile of formation pore pressure (blue circles) and minimum principal stress (pink squares $=$ MDT DP deployment; light green square $=$ LOT $)$ at Site C0009. The static borehole pressure $\left(P_{\mathrm{b}}\right)$ measured at each MDT deployment depth is shown for comparison (open black circles, dashed black line). $S_{\mathrm{Hmax}}$ calculated from DITF (denoted by "1"; crosses), derived from analysis of pressure records by Ito et al. [2013] (denoted by "2", solid red circles), and estimated from seismic anisotropy by Tsuji et al. [2011] (denoted by "3", red box) are also shown. The minimum horizontal stresses expected for slip on normal faults with an assumed friction coefficient $(\mu)$ of $0.4-0.6$ (orange-shaded area), $\mu=0.1$ (dashed line), and a uniaxial strain burial path for $\mathrm{K}_{0}$ values of $0.5-0.6$ (gray-shaded area) are shown for reference. The hydrostatic pressure (blue line) is computed assuming a seawater density of $1030 \mathrm{~kg}$ $\mathrm{m}^{-3}$. Lithostatic pressure (black line) is calculated by piecewise integration of density logs from Site C0002 (above $703.9 \mathrm{mbsf}$ ) and C0009 (703.9 mbsf to total depth). (b and c) Mohr diagram showing stress state for the LOT (green) and MDT (red) measurements, normalized to the effective vertical stress $\left(\sigma_{\mathrm{v}}{ }^{\prime}\right)$ for the shallow MDT and LOT tests (in Figure 9b) and the deep MDT test (in Figure 9c). Symbols in Figures 9b and 9c are the same as for Figure 9a. 
the lithostatic stress of $\sim 49.2 \mathrm{MPa}$, indicating that $S_{\text {hmin }}$ is likely the minimum principal stress at this depth. The values of $S_{\mathrm{hmin}}$ we report correspond to effective stress ratios $\left(K_{0}\right.$, defined as $\left.S_{\mathrm{hmin}}{ }^{\prime} / S_{\mathrm{v}}{ }^{\prime}\right)$ of $0.44,0.76-0.77$, and 0.39 for the LOT, shallow MDT, and deep MDT stress measurements, respectively.

[23] Drilling-induced tensile fractures (DITF) are present in resistivity images from the uppermost portion of the borehole (749-980 mbsf). This provides a constraint on the magnitude of the maximum horizontal principal stress $S_{\mathrm{Hmax}}$ by equation (2), informed by measured pore pressures from the nearby SP tests and the value of $S_{\mathrm{hmin}}$ from the hydraulic fracturing tests (Table 3; Figure 9). If we assume that DITF were present in the LOT interval at 708.6-715.7 mbsf (no image logs were collected at this depth), we can also estimate $S_{\text {Hmax }}$ in this interval. We find that for the MDT measurement, $S_{\text {Hmax }}=39.2-39.4 \mathrm{MPa}$ for the range of pore pressures measured by SP tests within a depth range of $2 \mathrm{~m}(30.1-31 \mathrm{MPa})$. This defines a stress state in which $S_{\mathrm{Hmax}}>S_{\mathrm{v}}>S_{\mathrm{hmin}}$, consistent with a strike-slip faulting regime slightly below failure for a friction coefficient of $\mu=0.4$ (Figure 9b, red Mohr circle). For the LOT measurement, we find that $S_{\mathrm{Hmax}}$ is equal to $S_{\mathrm{hmin}}$, consistent with a normal faulting regime $\left(S_{\mathrm{v}}>S_{\mathrm{Hmax}} \approx S_{\mathrm{hmin}}\right)$, and is near failure for $\mu=0.4$ (Figure $9 \mathrm{~b}$, green circle). Because no DITF were observed in the lower part of the borehole, we cannot obtain a constraint on $S_{\text {Hmax }}$ for the lower MDT hydraulic fracturing measurement from equation (2).

\section{Discussion and Implications}

\subsection{Permeability, Fluid Flow, and Drainage State of the Kumano Forearc Basin}

[24] The permeabilities obtained from our SP tests range from $\sim 6.5 \times 10^{-17}$ to $\sim 4 \times 10^{-14} \mathrm{~m}^{2}$ and exhibit a trend of slightly decreasing permeability with depth, as would be expected due to burial and consolidation (Figure 8). The highest value was obtained in Unit II, consistent with its greater abundance of sand and silt than the underlying lithologies [Expedition 319 Scientists, 2010b], but overall we observe no systematic correlation between lithologic unit and permeability (Figure 8). Notably, the permeability values we report are consistently $\sim 1-2$ orders of magnitude higher than those measured in laboratory tests on discrete core samples from Site C0009 [Boutt et al., 2012] or those estimated from measured porosities and laboratory-defined relations between permeability and porosity for Unit IV at Site C0009 and the basin fill using laboratory data from correlative lithologic units at Site C0002 (defined by seismic interpretation and age dating) as an analog (core samples were collected only from Unit IV at Site C0009) [e.g., Saffer and McKiernan, 2005; Gamage et al., 2011] (Figure 8). However, it is important to note that permeability values less than $\sim 10^{-15} \mathrm{~m}^{2}$ are at or near the stated lower limit for the SP device, so the permeabilities from our lowmobility response tests may be unreliable. If SP permeability values $<10^{-15} \mathrm{~m}^{2}$ are not considered, then only three of the MDT SP measurements exhibit a clear discrepancy with values estimated from laboratory measurements on cores (Figure 8).

[25] These differences could reflect anisotropy of 1-2 orders of magnitude, in which horizontal permeability sampled by the SP tests would be 10-100 times larger than the vertical permeability measured in laboratory tests on core samples, which were conducted parallel to the core axis. However, we deem this unlikely, based on measurements indicating that permeability anisotropy ratios $\left(k_{\mathrm{xx}}: k_{\mathrm{zz}}\right)$ in consolidating mudstones is generally less than $\sim 3-10$ [e.g., Clennell et al., 1999]. Alternatively, the difference could arise from a sampling bias in the selection of mud- or clay-rich core samples from Site $\mathrm{C} 0002$ for shore-based laboratory testing or in the selection of sand- or silt-rich SP test intervals at Site C0009, as is commonly the case. The difference may also reflect differences in sampling volume, based on the observation that permeability values obtained for the dual-packer tests (sampling interval of $\sim 1 \mathrm{~m}$ ) are greater than the SP values, which are in turn greater than those measured on core samples in the laboratory, possibly reflecting the sampling of larger and more permeable fractures with increasing measurement scale [e.g., Boutt et al., 2012].

[26] Pore pressures are nearly hydrostatic to the base of basin section and in the uppermost accretionary prism of Unit IV despite an average sedimentation rate of $\sim 780 \mathrm{~m} / \mathrm{Myr}$ over the last $\sim 1$ Myr. The lack of gas shows during pipe connections (when drilling and circulation were stopped) also suggests that formation pore fluid pressure did not exceed the static mud pressure, which was $\sim 10 \%$ above hydrostatic (Figure 9a). Our observations imply that drainage must be sufficiently rapid to keep pace with sedimentation and is consistent with a simplified 1-D model of sedimentation and loading above an impermeable substrate [Gibson, $1958]$ that incorporates hydraulic diffusivity $\left(C_{\mathrm{v}}\right)$ 
values for the basin section from laboratory measurements on core samples from Site $\mathrm{C} 0002$ $\left(C_{\mathrm{v}}=3.9 \times 10^{-8}\right.$ to $\left.1 \times 10^{-6} \mathrm{~m}^{2} / \mathrm{s}\right)$ [Guo et al., 2011]. For this range of $C_{\mathrm{v}}$, we predict maximum pore pressures of $0.05-1.6 \mathrm{MPa}$ at the base of the basin section, corresponding to pore pressure ratios of $\lambda^{*}=0.004-0.13$, in good agreement with the observations (where $\lambda^{*}=\left(P_{\mathrm{f}}-P_{\mathrm{h}}\right) /\left(P_{1}-P_{\mathrm{h}}\right)$, and $P_{\mathrm{f}}, P_{\mathrm{h}}$, and $P_{1}$ are the pore fluid pressure, hydrostatic pressure, and lithostatic pressure, respectively) (Figure 10). Because this simplified model assumes only one-dimensional consolidation and fluid flow, any lateral drainage along dipping strata would further enhance drainage [e.g., Guo et al., 2013]. If the higher values of permeability obtained from the SP tests are representative of the formation, the corresponding values of $C_{\mathrm{v}}$ would be $\sim 2.5 \times 10^{-7}$ to $\sim 6 \times 10^{-6} \mathrm{~m}^{2} / \mathrm{s}$ and would yield even lower pressures (cf. Figure 10).

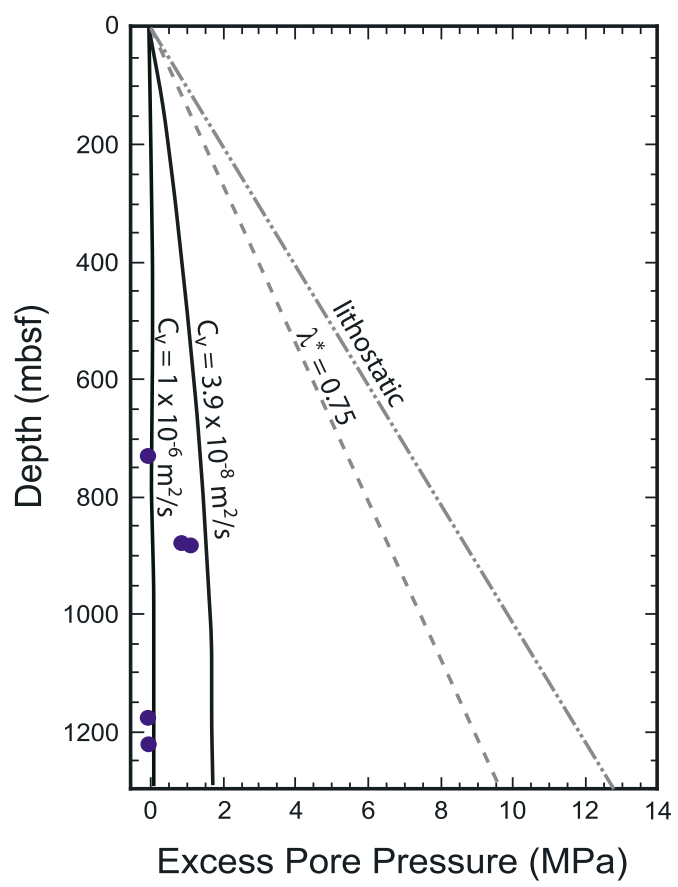

Figure 10. Excess pore fluid pressure within the Kumano Basin fill (Units I-III) computed for the case of 1-D sedimentation on an impermeable substrate and upward drainage [Gibson, 1958], for the range of time coefficients of consolidation $\left(C_{\mathrm{v}}\right)$ reported for core samples from the basin fill at Site C0002 [Guo et al., 2011], a total elapsed time of $3.8 \mathrm{Myr}$, and an average sedimentation rate of $355 \mathrm{~m} / \mathrm{Myr}$. Measured pore pressures are shown for comparison (blue circles). As noted in main text, the normalized pore pressure ratio (shown for comparison) is defined as follows: $\lambda^{*}=\left(P_{\mathrm{f}}-P_{\mathrm{h}}\right) /\left(P_{1}-P_{\mathrm{h}}\right)$, where $P_{\mathrm{f}}, P_{\mathrm{h}}$, and $P_{1}$ are the pore fluid pressure, hydrostatic pressure, and lithostatic pressure, respectively.
[27] One key implication of our permeability and pore pressure measurements is that despite the thick sediment section and its rapid deposition, the forearc basin is unlikely to act as a "pressure cap" or a flow barrier to trap fluids or fluid pressures in the underlying accretionary prism. Mud volcanoes farther arcward in the Kumano Basin suggest that in other areas, overpressures may occur within the basin sediment, perhaps owing to higher rates of deposition closer to terrestrial sources, flatterlying strata that do not allow lateral (updip) drainage, or additional sources of fluid from shallow hydrocarbon migration or flow from depth along faults transecting the accretionary wedge.

\subsection{Stress State}

[28] For all of our tests, the least principal stress is less than the vertical stress $\left(S_{\mathrm{v}}\right)$, and we therefore interpret it to be the minimum horizontal stress $S_{\text {hmin }}$, assuming that the principal stresses at these depths are horizontal and vertical. Static borehole pressures measured during the deployment of the MDT indicate pressures at the LOT depth that were $0.7 \mathrm{MPa}$ (Table 3) greater than the least principal stress (" $P_{\mathrm{b}}$ MDT", Figure 9). The actual annular pressures during drilling would have been even greater due to additional pressure generated during circulation. During drilling of this interval, mud losses of $\sim 10-60 \mathrm{~m}^{3} /$ day were noted and were observed to increase with increased mud weight (1080 versus $\left.1100 \mathrm{~kg} \mathrm{~m}^{-3}\right)$ [Expedition 319 Scientists, 2010b]. We interpret that these fluid losses resulted from borehole pressures that exceeded the least principal stress, resulting in the loss of fluids into the formation. The mud losses, along with observed washout of the borehole in this interval, are consistent with the interpreted magnitude of $S_{\text {hmin }}$ from the LOT (Figure 9a).

[29] The presence of DITF in the interval from 749 to $980 \mathrm{mbsf}$, taken together with measured values of $S_{\mathrm{hmin}}$, formation pore fluid pressure, and estimated borehole pressure $\left(P_{\mathrm{b}}\right)$, also allows us to estimate $S_{\text {Hmax }}$ and therefore to fully define the stress tensor at the leak-off test (LOT) at $708.6 \mathrm{mbsf}$ and upper MDT hydraulic fracturing measurement at 876.9 mbsf. For the leak-off test measurement, $S_{\mathrm{Hmax}}$ obtained by equation (2) is equal to $S_{\text {hmin }}$ (30.24 MPa) (Figure 9; Table 3). For the MDT $S_{\text {hmin }}$ measurement, $S_{\mathrm{Hmax}}$ is $38.9-39.1 \mathrm{MPa}$, considerably larger relative to $S_{\mathrm{hmin}}$ and $S_{\mathrm{v}}$ than for the LOT test (Figure 9). These values of $S_{\mathrm{Hmax}}$, taken together with the adjacent SP pore pressure measurements (Table 2), indicate maximum horizontal effective 
stresses of 2.05 MPa for the LOT and $8.2-8.6 \mathrm{MPa}$ for the MDT test.

[30] The $S_{\text {Hmax }}$ value we calculate for the shallow MDT test interval is consistent with that inferred from seismic anisotropy based on a two-ship vertical seismic profile experiment at this site, which reported a value of $S_{\text {Hmax }}$ slightly $(\sim 2.7-5.5 \mathrm{MPa})$ larger than $S_{\mathrm{v}}$ [Tsuji et al., 2011] but is higher than a value of $S_{\mathrm{Hmax}}=35.0 \mathrm{MPa}$ estimated by Ito et al. [2013] from detailed analysis of the test pressure records (Figure 9). The DITF and seismic anisotropy results suggest a strike-slip faulting regime in which $S_{\mathrm{Hmax}}>S_{\mathrm{v}}>S_{\mathrm{hmin}}$, whereas the estimate reported by Ito et al. [2013] reflects a normal faulting regime $\left(S_{\mathrm{v}}>S_{\mathrm{H} \max } \approx S_{\mathrm{hmin}}\right)$ (Figure $9 \mathrm{~b}$ ). $S_{\mathrm{H} \max }$ for the deeper MDT hydraulic-fracture (HF) measurement at 1533.9 mbsf (beneath the forearc basin) has also been constrained indirectly, using measured values of $S_{\mathrm{hmin}}$ (despite the low confidence in this result; Saffer et al. [2010]). Ito et al. [2013] estimate $S_{\text {Hmax }}$ from relative stress magnitudes inferred from the diametrical deformation of a core sample from $\sim 1540 \mathrm{mbsf}$, located $\sim 8 \mathrm{~m}$ below the deep MDT measurement of $S_{\text {hmin }}$. They obtain a value of $S_{\mathrm{H} \max }=55.1 \mathrm{MPa}$, also indicating a strike-slip faulting regime.

[31] In contrast to the MDT result, horizontal stresses from the LOT test in the uppermost part of the riser hole define a normal faulting stress regime in which $S_{\mathrm{v}}>S_{\mathrm{Hmax}} \approx S_{\mathrm{hmin}}$ (Figure 9). Our results, in combination with the results of Ito et al. [2013] and Tsuji et al. [2011], suggest that the horizontal stresses increase with depth below the LOT interval at $708.6 \mathrm{mbsf}$ (Figure 9) and transition from a normal faulting to a possible strike-slip faulting regime. This transition appears to occur over a depth interval of only $\sim 175 \mathrm{~m}$ (Figure 9). It is also possible that the differences in horizontal stress magnitudes between the LOT and shallow MDT test over this short distance are related to lithologic and associated strength variations down-section between Units II and III (Figure 3). In this case, the lower value of $S_{\mathrm{hmin}}$ for the LOT interval could reflect the presence of stronger sand-rich strata in Unit II that support larger differential stress than the muds of Unit III.

[32] At Site C0002, located $20 \mathrm{~km}$ seaward, analysis of borehole breakouts indicates a normal faulting regime throughout the basin, transitioning to a strikeslip or reverse faulting regime below the unconformity marking the base of the basin fill [Chang et al., 2010]. The difference in stress state within the forearc basin sediments between Sites C0009 (normal fault ing transitioning to a strike-slip regime; Figure 9) and $\mathrm{C} 0002$ (normal faulting regime) is consistent with the observation of abundant active normal faults in the seawardmost part of the Kumano Basin and with the lack of active normal faulting farther landward in the

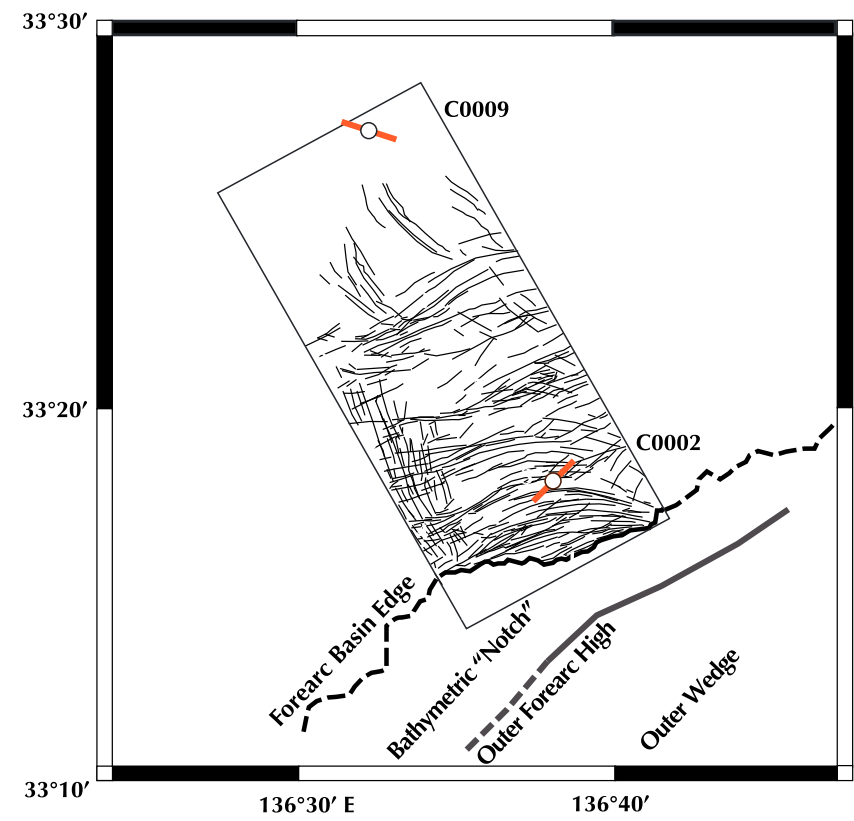

Figure 11. Mapped active normal faults in the Kumano Basin within the 3-D seismic survey [after Sacks, 2011]. $S_{\text {Hmax }}$ orientations determined from borehole breakouts and DITF at Sites C0002 and C0009 are also shown. 
vicinity of Site C0009 [e.g., Gulick et al., 2010; Moore et al., 2009; Moore et al., 2013] (Figure 11). It is also broadly consistent with the rotation of $S_{\mathrm{Hmax}}$ from an orientation nearly orthogonal to the convergence direction at Site C0002, to subparallel to convergence at Site C0009, perhaps suggesting that stresses in the landward portion of the basin and upper wedge are driven by the regional tectonic processes, whereas stresses measured at Site C0002 reflect local effects of topography or slip on the shallow megasplay fault [e.g., Byrne et al., 2009; Lin et al., 2010; Conin et al., 2012].

\section{Conclusions}

[33] As part of the first riser operations conducted in scientific ocean drilling, we deployed the MDT wireline tool to measure the least principal stress, pore fluid pressure, and permeability in the sediments of the Kumano Basin and underlying accretionary prism. Our results indicate that pore pressure is near hydrostatic throughout the basin section and are consistent with 1-D models of coupled sedimentation and consolidation [e.g., Gibson, 1958] (Figure 10). This indicates that the basin should not act as a "cap" to trap pressures in the hanging wall of the subduction megathrust. Measured permeabilities are consistently $\sim 1-2$ orders of magnitude higher than those measured on core samples, suggesting a scale dependence [e.g., Boutt et al., 2012] (Figure 8).

[34] Our stress measurements reveal that $S_{\mathrm{hmin}}$ is less than $S_{\mathrm{v}}$ and therefore represents the least principal stress. However, values of $S_{\text {hmin }}$ obtained from leak-off testing are substantially lower than those from an MDT hydraulic fracturing test conducted only $\sim 175 \mathrm{~m}$ away. In combination with constraints on $S_{\text {Hmax }}$ from the presence of drillinginduced tensile fractures, the suite of downhole measurements allows us to quantify the full stress tensor at specific depths. The results suggest either a normal or strike-slip faulting regime in the basin and uppermost accretionary prism. Although the results are ambiguous, they are broadly consistent with observed faulting patterns in the basin [e.g., Moore et al., 2013] and with the orientation and magnitude of $S_{\mathrm{hmin}}$ determined from wellbore breakouts [Chang et al., 2010; Wu et al., 2012]. The successful measurement of stress, pore pressure, and permeability as part of IODP operations represents an important capability for future tectonic and hydrogeologic drilling programs.

\section{Acknowledgments}

[35] This research used data obtained as part of the Integrated Ocean Drilling Program (IODP). We thank the CDEX operations group, Operations Superintendents, and IODP Expedition \#319 scientists who made the downhole measurements possible. The clarity of this paper was improved by comments from two anonymous reviewers. This research was supported by post-expedition funding from the Consortium for Ocean Leadership to D.S.

\section{References}

Ando, M. (1975), Source mechanisms and tectonic significance of historical earthquakes along the Nankai Trough, Japan, Tectonophys., 27, 119-140, doi:10.1016/0040-1951(75)90102-X.

Ashi, J., S. Lallemant, H. Masago, and the Expedition 315 Scientists (2009), Expedition 315 summary, in M. Kinoshita, H. Tobin, J. Ashi, G. Kimura, S. Lallemant, E. J. Screaton, D. Curewitz, H. Masago, K. T. Moe, and the Expedition 314/ 315/316 Scientists, Proc. IODP, 314/315/316, Integrated Ocean Drilling Program Management International, Inc., Washington, DC, doi:10.2204/iodp.proc.314315316.121.2009.

Becker, K., and E. E. Davis, (2005), A Review of CORK Designs and Operations during the Ocean Drilling Program, in Proc. Ocean Drill. Prog, edited by A. Fisher, T. Urabe, and A. Klaus, 301: College Station, TX (Ocean Drilling Program), doi:10.2204/iodp.proc.301.104.2005.

Becker, K., A. T. Fisher, and E. E. Davis (1997), The CORK experiment in hole 949C: Long-term observations of pressure and temperature in the Barbados accretionary prism, in Proc. Ocean Drill. Program Sci. Results, edited by T. H. Shipley et al., Ocean Drilling Program, 156: College Station, TX, 247-252.

Bekins, B. A., A. M. McCaffrey, and S. J. Dreiss (1995), Episodic and constant flow models for the origin of lowchloride waters in a modern accretionary complex, Water Resour. Res., 31, 3205-3215.

Boutt, D. F., et al. (2012), Scale dependence of in-situ permeability measurements in the Nankai accretionary prism: The role of fractures, Geophys. Res. Lett., 39, L07302, doi:10.1029/ 2012 GL051216.

Byrne, T., and D. Fisher (1990), Evidence for a weak and overpressured decollement beneath sediment-dominated accretionary prisms, J. Geophys. Res., 95, 9081-9097.

Byrne, T. B., W. Lin, A. Tsutsumi, Y. Yamamoto, J. C. Lewis, K. Kanagawa, Y. Kitamura, A. Yamaguchi, and G. Kimura (2009), Anelastic strain recovery reveals extension across SW Japan subduction zone, Geophys. Res. Lett., 36, L23310, doi:10.1029/2009GL040749.

Chang, C., L. C. McNeill, J. C. Moore, W. Lin, M. Conin, and Y. Yamada (2010), In situ stress state in the Nankai accretionary wedge estimated from borehole wall failures, Geochem. Geophys. Geosyst., 11, Q0AD04, doi:10.1029/ 2010GC003261.

Calahorrano, A., V. Sallares, J.-Y. Collot, F. Sage, and C. Ranero (2008), Nonlinear variations of the physical properties along the southern Ecuador subduction channel: Results from depth-migrated seismic data, Earth Planet. Sci. Lett., 267, 453-467, doi:10.1016/j.epsl.2007.11.061.

Clennell, M. B., D. N. Dewhurst, K. M. Brown, and G. K. Westbrook (1999), Permeability anisotropy of consolidated and unconsolidated clays, in Muds and Mudstones: Physical 
and Fluid Flow Properties, edited by A. C. Aplin, A. J. Fleet, and J. H. S. Macquaker, 79-96, Geological Society, London. Conin, M., P. Henry, V. Godard, and S. Bourlange (2012), Splay fault slip in a subduction margin, a new model of evolution, Earth Planet. Sci. Lett., 341-344, 170-175, doi:10.1016/j.epsl.2012.06.003.

Davis, D. M., J. Suppe, and F. A. Dahlen (1983), Mechanics of fold-and-thrust belts and accretionary wedges, J. Geophys. Res., 88, 1153-1172, doi:10.1029/JB088iB02p01153.

Davis, E. E., K. Becker, K. Wang, K. Obara, Y. Ito, and M. Kinoshita (2006), A discrete episode of seismic and aseismic deformation of the Nankai trough subduction zone accretionary prism and incoming Philippine Sea plate, Earth Planet. Sci. Lett, 242, 73-84.

Expedition 319 Scientists (2010a), Methods, in Proc. IODP, D. Saffer, L. McNeill, T. Byrne, E. Araki, S. Toczko, N. Eguchi, K. Takahashi, and the Expedition 319 Scientists, Integrated Ocean Drilling Program Management International, Inc., 319: Tokyo, doi:10.2204/iodp.proc.319.102.2010.

Expedition 319 Scientists (2010b), Site C0009, in Proc. IODP, D. Saffer, L. McNeill, T. Byrne, E. Araki, S. Toczko, N. Eguchi, K. Takahashi, and the Expedition 319 Scientists, Integrated Ocean Drilling Program Management International, Inc., 319: Tokyo, doi:10.2204/iodp.proc.319.103.2010.

Fisher, A. T., and G. Zwart (1996), The relation between permeability and effective stress along a plate-boundary fault Barbados accretionary complex, Geology, 24, 307-311.

Flemings, P. B., et al. (2008), Pore pressure penetrometers document high overpressure near the seafloor where multiple submarine landslides have occurred on the continental slope, offshore Louisiana, Gulf of Mexico, Earth Planet. Sci. Lett., 269, 309-325, doi:10.1016/j.eps1.2007.12.005.

Gamage, K., E. Screaton, B. Bekins, I. Aiello (2011), Permeability-porosity relationships of subduction zone sediments, Mar. Geol., 279, 19-36, doi:10.1016/j.margeo.2010.10.010.

Gibson, R. E. (1958), The progress of consolidation in a clay layer increasing in thickness with time, Geotechnique, 8, 171-182.

Gulick, S. P. S., et al. (2010), Rapid forearc basin uplift and megasplay fault development from 3D seismic images of Nankai Margin off Kii Peninsula, Japan, Earth Planet. Sci. Lett., 300, 55-62.

Guo, J., W. J. Likos, M. B. Underwood, and D. M. Saffer (2011), Data Report: Consolidation characteristics of sediments from Sites C0002, C0006, and C0007, IODP Expeditions 315 and 316, NanTroSEIZE Stage 1, Proc. IODP, 314/315/316.

Guo, J., M. B. Underwood, W. Likos, and D. M. Saffer (2013), Apparent overconsolidation of mudstones in the Kumano Basin of southwest Japan: Implications for fluid pressure and fluid flow within a forearc setting, Geochem. Geophys. Geosyst., doi:10.1002/ggge.20042.

Haimson B. C., and F. H. Cornet (2003), ISRM suggested method for rock stress estimation: Hydraulic fracturing and hydraulic testing of pre-existing fractures, Intl. J. Rock Mech. Mining Sci., 40, 1011-1020.

Ito, Y., and K. Obara (2006), Dynamic deformation of the accretionary prism excites very low frequency earthquakes, Geophys. Res. Lett., 33, L02311, doi:10.1029/2005GL025270.

Ito, T., A. Funato, W. Lin, M.-L. Doan, D. F. Boutt, Y. Kano, H. Ito, D. M. Saffer, L. C. McNeill, T. Byrne, and K.-T. Moe (2013), Determination of stress state in deep subsea formation by combination of hydraulic fracturing in situ test and core analysis: A case study in the IODP Expedition 319, J. Geophys. Res., doi:10.1002/jgrb.50086.
Kagami, H., et al. (1986), Init. Rep. Deep Sea Drill. Proj., 87, U.S. Government Printing Office, Washington, DC, pp. 927 , doi:10.2973/dsdp.proc.87.1986

Kamei, R., R. G. Pratt, and T. Tsuji (2012), Waveform tomography imaging of a megasplay fault system in the seismogenic Nankai subduction zone, Earth Planet. Sci. Lett., 317-318, 343-353, doi:10.1016/j.epsl.2011.10.042.

Karig, D. E., et al. (1975), Init. Rep. Deep Sea Drill. Proj., 31, pp. 916, U.S. Government Printing Office, Washington, DC, doi:10.2973/dsdp.proc.31.1975

Karig, D. E. (1990), Experimental and observational constraints on the mechanical behaviour in the toes of accretionary prisms. In R. J. Knipe, and E. H. Rutter, (Eds.), Deformation Mechanisms, Rheology, and Tectonics. Geol. Soc. Spec. Publ. London, 54: 383-398.

Kinoshita, M., H. Tobin, J. Ashi, G. Kimura, S. Lallemant, E. J. Screaton, D. Curewitz, H. Masago, K. T. Moe, and the Expedition 314/315/316 Scientists (2009), Proc. IODP, 314/315/316: Washington, DC (Integrated Ocean Drilling Program Management International, Inc.), doi:10.2204/iodp.proc.314315316.2009.

Lin, W., et al. (2010), Present-day principal horizontal stress orientations in the Kumano forearc basin of the southwest Japan subduction zone determined from IODP NanTroSEIZE drilling Site C0009, Geophys. Res. Lett., 37, L13303, doi:10.1029/2010GL043158.

Long, H., P. B. Flemings, J. Germaine, and D. Saffer (2011), Consolidation and overpressure near the seafloor in the Ursa Basin, Deepwater Gulf of Mexico, Earth Planet. Sci. Lett., 305, 11-20, doi:10.1016/j.epsl.2011.02.007.

Miyazaki, S., and K. Heki (2001), Crustal velocity field of southwest Japan: Subduction and arc-arc collision, $J$. Geophys. Res., 106, 4305-4326.

Moe, K.T., et al. (2012), Operational review of the first wireline in situ stress test in scientific ocean drilling, Sci. Drill., doi: 10.2204/iodp.sd.13.06.2011

Moore, G. F., T. H. Shipley, P. L. Stoffa, D. E. Karig, A. Taira, S. Kuramoto, H. Tokuyama, K. Suyehiro, (1990), Structure of the Nankai Trough accretionary zone from multichannel seismic reflection data, J. Geophys. Res., 95, 8753-8765.

Moore, G. F., B. Boston, A. F. Sacks, and D. M. Saffer (2013), Analysis of Normal Fault Populations in the Kumano Forearc Basin, Nankai Trough, Japan: 1 Multiple Orientations and Generations of Faults from 3-D Coherency Mapping, Geochem. Geophys. Geosyst., doi:10.1002/ggge.20119, in press.

Moore, G. F., et al. (2001), New insights into deformation and fluid flow processes in the Nankai accretionary prism: Results of Ocean Drilling Project Leg 190, Geochem. Geophys. Geosyst., 2, doi:10.1029/2001GC000166.

Moore, J. C., C. Chang, L. McNeill, M. K. Thu, Y. Yamada, and Huftile, G. (2011), Growth of borehole breakouts with time after drilling: Implications for state of stress, NanTroSEIZE transect, SW Japan, Geochem. Geophys. Geosyst., 12, Q04D09, doi:10.1029/2010GC003417.

Moore, G. F., et al. (2009), Structural and Seismic Stratigraphic Framework of the NanTroSEIZE Stage 1 Transect, in NanTroSEIZE Stage 1: Investigations of Seismogenesis, Nankai Trough, Japan, Proc. Integr. Ocean Drill. Program, 314/ 315/316, doi:10.2204/iodp.proc.314315316.102.2009.

Moore, G., et al. (2007), Three-dimensional splay fault geometry and implications for tsunami generation, Science, 318 , 1128-1131, doi:10.1126/science.1147195. 
Moran, K., W. Bruckmann, V. Feeser, R. G. Campanella (1993), In situ stress conditions at Nankai Trough, Site 808, in I. A. Hill, A. Taira, J. V. Firth, et al, (1993), Proc. ODP, Sci. Results, 131: College Station, TX (Ocean Drilling Program), 283-291.

Reece, J. S., P. B. Flemings, B. Dugan, H. Long, and J. T. Germaine (2012), Permeability-porosity relationships of shallow mudstones in the Ursa Basin, northern deepwater Gulf of Mexico, J. Geophys. Res., 117, B12102, doi:10.1029/ 2012JB009438

Sacks, A. (2011), Principal Axes of Stress and Strain in the Kumano Forearc Basin from Inversion of a Normal Fault Population Mapped in a 3-D Seismic Volume, Nankai Trough, SW Japan, M.S. Thesis, The Pennsylvania State University, 85 pp.

Saffer, D. M., and A. W. McKiernan (2005), Permeability of underthrust sediments at the Costa Rican subduction zone: Scale dependence and implications for dewatering, Geophys. Res. Lett., 32, L02302, doi:10.1029/2004GL021388.

Saffer, D. M., and H. Tobin (2011), Hydrogeology and mechanics of subduction zone forearcs: Fluid flow and pore pressure, Annu. Rev. Earth Planet. Sci., 39, doi:10.1146/annurev-earth040610-133408.

Saffer, D. M., and B. A. Bekins (1998), Episodic fluid flow in the Nankai accretionary complex: Timescale, geochemistry, and fluid budget, J. Geophys. Res., 103, 30,351-30,370.

Saffer, D., L. McNeill, T. Byrne, E. Araki, S. Toczko, N. Eguchi, K. Takahashi, and the Expedition 319 Scientists (2010), Proc. IODP, 319: Tokyo (Integrated Ocean Drilling Program Management International, Inc.). doi:10.2204/iodp.proc.319.2010, $388 \mathrm{pp}$.

Saito, S., M. B. Underwood, Y. Kubo, and the Expedition 322 Scientists (2010), Proc. IODP, 322, doi:10.2204/iodp. proc.322.2010.

Scholz, C.H. (1998), Earthquakes and friction laws, Nature, 391, 37-42.

Screaton, E. J., B. Carson, and G. P. Lennon, (1995), Hydrogeologic properties of a thrust fault within the Oregon Accretionary Prism, J. Geophys. Res.., 20025-20035.

Seno, T., S. Stein, and A. E. Gripp (1993), A model for the motion of the Philippine Sea plate consistent with NUVEL-1 and geological data, J. Geophys. Res., 98, 17,941-17,948.
Spinelli, G. A., D. M. Saffer, M. B. Underwood (2006) Hydrogeologic responses to three-dimensional temperature variability, Costa Rica subduction margin. J. Geophys. Res., 111, B04403, doi:10.1029/2004JB003436.

Stewart, G., and M. Wittman, (1979), Interpretation of the pressure response of the repeat formation tester, Soc. Petrol. Eng., $54^{\text {th }}$ annual technical conference, Las Vegas, NV, paper \#8362.

Strasser, M., et al.(2009), Origin and evolution of a splay fault in the Nankai accretionary wedge, Nat. Geosci., doi:10.1038/ NGE0609.

Taira, A., I. Hill, et al. (1991), Proc. Ocean Drill. Prog., Initial Reports, Volume 131A: College Station, Texas, Ocean Drilling Program, $434 \mathrm{p}$.

Tobin, H. J., and Saffer, D.M. (2009), Elevated fluid pressure and extreme mechanical weakness of a plate boundary thrust, Nankai Trough subduction zone, Geol., 37, 679-682; doi:10.1130/G25752A.

Tsuji, T., H. Tokuyama, P. Costa Pisani, and G. Moore (2008), Effective stress and pore pressure in the Nankai accretionary prism off the Muroto Peninsula, southwestern Japan, J. Geophys. Res., 113, B11401, doi:10.1029/ 2007JB005002.

Tsuji, T., et al. (2011), In situ stress state from walkaround VSP anisotropy in the Kumano basin southeast of the Kii Peninsula, Japan, Geochem. Geophys. Geosyst., 12, Q0AD19, doi:10.1029/2011GC003583.

Wang, K., and Davis, E. E. (1996), Theory for the propagation of tidally induced pore pressure variations in layered subseafloor formations, J. Geophys. Res., 101, 11483-11495.

White, A. J., Traugott, M.O., and Swarbrick, R. E. (2002), The use of leak-off tests as means of predicting minimum in-situ stress, Pet. Geosci., 8, 189-193, doi:10.1144/ petgeo.8.2.189

Wu, H.-Y., M. Kinoshita, and Y. Sanada (2012), Stress state estimation by geophysical logs in NanTroSEIZE Expedition 319-Site C0009, Kumano Basin, southwest Japan, Geophys. Res. Lett., 39, L18303, doi:10.1029/2012GL053086.

Zoback, M. D. (2007), Reservoir Geomechanics, Cambridge Univ. Press, New York. 